\title{
Glacier Area Change over Past 50 Years to Stable Phase in Drass Valley, Ladakh Himalaya (India)
}

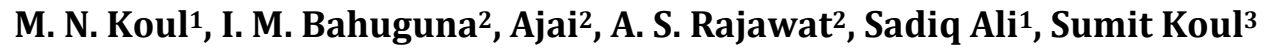 \\ ${ }^{1}$ Department of Geography, University of Jammu, Jammu, India \\ ${ }^{2}$ Space Application Centre, Ahmadabad, India \\ ${ }^{3}$ Department of Statistics, University of Jammu, Jammu, India \\ Email:mnkaul_2004@yahoo.com
}

Received 28 July 2015; accepted 28 March 2016; published 31 March 2016

Copyright (C) 2016 by authors and Scientific Research Publishing Inc.

This work is licensed under the Creative Commons Attribution International License (CC BY). http://creativecommons.org/licenses/by/4.0/

(c) $\underset{\mathrm{EY}}{0}$ Open Access

\section{Abstract}

Glaciers are dynamic reservoirs of constantly exchanging mass with parts of global hydrological system, process by which glaciers gain or lose snow and ice and establish a link between climate, glacier mass and glacier fluvial dynamics related directly to the behaviour of climate. Here, we report on glacier status over the past 50 years (1962-2013) on remotely-sensed volumetric changes of glaciers in Drass glacier basin, Ladakh Mountain, North-West Himalaya. Drass basin houses 150 glaciers of different dimensions predominantly (nearly $75 \%$ ) by small sized glaciers. The glaciers monitored on multi-temporal satellite images of the year's 2001, 2013 for short-term basis, and, Survey of India topographic sheets of 1965 (surveyed in 1963) on long-term basis. Machoi glacier has been selected for detailed study to assess health and fluctuation record on which observation has been made since the year 1875. The long-term monitoring (1965-2001) of 81 glaciers shows that $12.5 \%$ of glaciers have gained the area whereas $14 \%$ of large glaciers lost area $5 \%$ to $15 \%$, and remaining $73 \%$ glaciers lost area marginally $(<5 \%)$. The short-term monitoring shows that $80 \%$ glaciers do not show any change in area; even large glaciers vacated $0.64 \%-2.6 \%$ area and small glaciers $1.68 \%$ - 9\% glacier area. The trends in annual, seasonal and monthly maximum $/ \mathrm{minimum}$ temperature and precipitation (snowfall and rainfall) of Drass for period 1987-2013 show that two different patterns of weather conditions: 1988-2001, cold moist winters with dry summers, and 2002-2013, a period of long winters and cool and moist summers, corroborate with transitional phase of glacier behaviour. This phenomenon has resulted in incorporating no change in area of $80 \%$ of glacier (120 glaciers) and remaining 20 percentage of glaciers show marginal loss in area. The positive balance mass for last four years (2011-2014) in benchmark Machoi glacier with cumulative specific balance $+0.16 \mathrm{~m} \mathrm{w} . \mathrm{e} / \mathrm{km}^{2} / \mathrm{yr}$ further indicates about the stability phase of the glaciers. 


\section{Keywords}

\section{Climate Change, Stability of Himalayan Glaciers, Remote Sensing GIS, Glacier Mass Balance, Benchmark Glacier}

\section{Introduction}

Ladakh, a most heavily glaciated region of India, as it houses nearly 50\% glaciers of India confined to protracted zones of High Himalaya-Karakorum (Zanskar, Ladakh) ranges that contain some of the world's highest peaks and largest glaciers outside the polar region. It contains nearly 5000 glaciers encompassing glacier area of 3187 $\mathrm{km}^{2}$ and total ice volume of $815.62 \mathrm{~km}^{3}$. The region mainly influenced by the air mass of Westerly particularly Western disturbances during the winter season that results in snow cover extent in higher reaches and glacier melt water production in lower reaches leads to development of a watershed of the Indus. The Indus contributes a lot to Agrarian as well in Industrial economy of North India by providing perennial irrigation as well generating hydroelectric power. Snow and glacial melt water contribute 400 - 800 cubic km water along with 100 tons hectare/yrs of sediments which is of great economic value (Bahadur, 2000) [1]. The glaciers are dynamic reservoirs of constantly exchanging mass with parts of global hydrological system, process by which glaciers gain or lose snow and ice and establish a link between climate, glacier mass and glacier fluvial dynamics. Variability of climate and its impact on glacier mass balance have been reported from Alps and Rocky (Fujita, 2008; Bitz and Battisti, 1999; Bowling, 1977) [2]-[4]. However, conflicting signal of change in climate, in terms of change in temperature, snowfall and snow extent is reported from West Himalaya (Yadav et al., 2004; Fowler and Archer, 2006; Bhutiyani et al., 2007; Koul and Ganjoo, 2010) [5]-[8]. The studies have investigated the role of meteorological parameters in governing the snow cover extent and it has been found that annual change in glacier mass balance is largely due to winter and spring time anomalies in accumulation which in turn are mainly due to anomalies in precipitation and temperature (Kaul, 1986) [9].

The recent publication by Intergovernmental Panel on Climate Change in Fourth and Fifth Assessment report generated a lot of debates about the status of Himalayan Glaciers. The present study is to understand how in having high relative relief that is cause of perturbation in ambient temperature generating katabatic winds in glacier valley do affect the extent and terminus of glacier valley. Therefore, we assess regional differences in extent of glaciers in Drass glacier valley, Higher Himalaya from remotely measured glacier snout changes and glacier area changes between 1965 and 2013 and detailed field truth collected during 2011-2014 to assess overall behaviour of glaciers in the valley. Further, our objective is to determine if the glaciers in this valley at present behave in steady state phase and relate the same to present day climatic and other to po-climatic factors generated by high relative relief.

\section{Regional Setting}

The Kargil region forms a vast mountainous region between the Great Himalaya Range in the South-southwest and Indus Valley in the north-east and occupies southern part of Ladakh. It has nearly 1796 glaciers, confined in Upper Indus basin, housed in Zaskar, Suru and Drass sub basin. Drass sub basin has 150 glaciers encompassing an area of $152.6775 \mathrm{~km}^{2}$ with ice volume of $62.02 \mathrm{~km}^{3}$.

Drasssub basin is the Vth order basin of IVth order Indus and it extends between the Gumri (close to Zoji-La) in the west to Kargil in the east. Zoji-La is gateway to Drass, situated on National Highway 1-A road connecting Srinagar with Kargil, and Leh (Ladakh). The Srinagar-Kargil road remains closed to vehicular traffic during winter season due to closure of Zoj-La pass as result of heavy snowfall (Figure 1). Drass valley is encircled by ridge crusts of higher peaks (5200 m - $6100 \mathrm{~m}$ ) of Himalaya and ridges descend precipitously. The study region is a bi-armed valley system lying between Great Himalaya and Drass Mountain. The magnitude of high relief and overall steepness of slopes provide an overwhelming impression that region has distinct climatic condition between that of Central Asia and monsoon land of South Asia.

\section{General Climatic Characteristics}

Drasssub basin or Drass valley holds special geographical significance for study of snow cover changes in the 


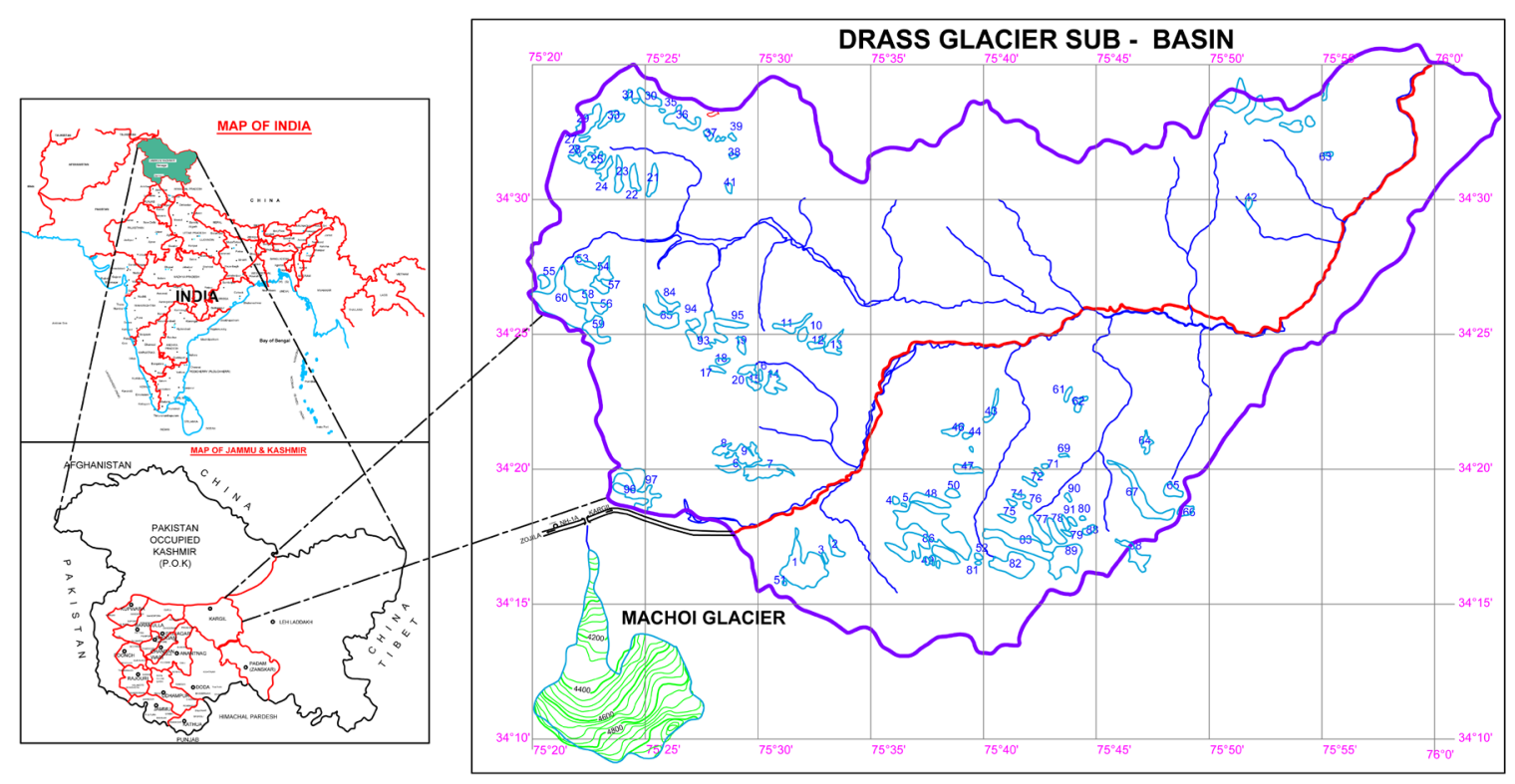

Figure 1. Location map of Drass glacier sub-basin and Machol glacier, Kargil Ladakh.

light of climate change phenomenon, if any. The valley has a distinct climatic characteristic due to its location in the shadow zone of Great Himalaya having an aerodynamic link with the air mass of westerly air flow and westerly disturbances (originating from Mediterranean and Caspian ocean) moving aloft the Pamir Range. The air mass develops cold high air pressure at higher altitude that ultimately sinks to lower altitude giving rise to cold anticyclone leading to production of thermal gradient during winter season (October to May) that is responsible for anchoring southerly jet. The study region has cold sub arid type of climate. The winters are long chilly (mean minimum temperature $-15^{\circ} \mathrm{C}$ to $-25^{\circ} \mathrm{C}$ ), lasting November to May. Summers are short (June to September) mild (temperature varies between $-8^{\circ} \mathrm{C}$ to $25^{\circ} \mathrm{C}$ ). Nearly $72 \%$ of its annual precipitation is received by Western Disturbances that is confined to November to May which sometimes prolongs to summers as well otherwise summers get scanty rains. During last one decade, the region is getting some precipitation during summers as well through Westerly thus showing sign of climatic shift.

\section{Methods}

Most of the glaciers in Drass valley are located in remote and treacherous terrain that is inaccessible and not connected with motor able road. The monitoring of glaciers is difficult by direct field methods .Remote Sensing has advantage of giving synoptic view of the region on regular basis. The IRS-IC-LISS III (October, 2001 and 2013) data was provided for Drass basin by Space Application Centre (SAC) at pixel resolution of $23.5 \mathrm{~m}$ for the detailed study. The base map of the area was prepared from Survey of India (SOI) 1965 topographic maps of the scale 1:50,000. Only seven topographic sheets of Drass basin were available that covered 115 glaciers out of these 81 glaciers $\left(>0.1 \mathrm{~km}^{2}\right)$ selected for detail study. All the satellite images were geo-referenced using SOI topographic maps. Images co-registered with each other resembled to same resolution. The glacier boundaries were delineated using topographic maps and the area was digitized using topographic Geographic Information system. The boundaries of glaciers delineated by visual interpretations and manual techniques using GIS False colour made from visible and near infra red satellite images could be used successfully to map various glacial features such as glacier boundary, accumulation area,, ablation area, equilibrium line, moraines etc.

Shape file of the basin as well the glacier boundaries delineated from the satellite images was over lapped on topographic sheets and then it was digitized using Geographic Information System techniques.

Machhoi glacier located at the road head, and selected as benchmark glacier in Drass basin, monitored and studied by many geologist as well glaciologist for last one hundred thirty years. Hence selected, detailed mass balance studies, to assess its fluctuation behaviour. Under the stratigraphic system, net mass balance is the net change in mass of glacier at the end of ablation season, relative to previous year. Under this system, the specific net ablation and net accumulation carried out in the field through ablation stakes measurement, fixed firmly in 
the ablation zone of glacier by steam ice drill (Heuck). Net accumulation measurements carried out by snow pit measurement of residual snow in the accumulation zone of the glacier at the end of ablation season (generally in September). Snow densities measured were for water equivalent during field season 2011-2012, 2012-2013 and 2013-2014.

The location and sources of meteorological data used in this study chosen, for their proximity to glaciers length of their records. The meteorological data of Drassis monitored by Indian Meteorology Department (IMD) and Snow and Avalanche Establishment (Government of India), adopting standard meteorological practices. The data for record period of 28 years (1987-2013) is used to assess seasonal changes, if any in monthly mean maximum, mean minimum temperature and precipitation as tool to glacier stratigraphic system (Nov, Dec. previous year, and Jan to Oct. current year). Hence, under this system length of season and duration of "mass balance year of glacier year" varies. The mass balance year is divided in to winter (Nov-Mar), late winter (Mar-May), summer (Jun-Aug), late summer (Sep-Oct) is used in this study to isolate the inter-seasonal signals. The monthly mean maximum, minimum temperature and snowfall been analysed for each phase by fitting linear least square trend line (1988-2000, 2001-2008, and 2008-2013) to assess the impact of temperature and precipitation on the health of glaciers. The significance of trend line is shown by probability value ( $\mathrm{P}$ value) for significance level 0.05 . The value of $R$-square $\left(R^{2}\right)$ from regression is used to show correlation between glacier fluctuation and external climatic variables like temperature and precipitation (Haeberli and Beniston, 1998; Kulkarni et al., 2002; Singh et al., 2005) [10]-[12].

\section{Results}

Glaciers are sensitive to climate change. The overall growth or decay of glaciers depends on the temperature of the ambient climate largely and to input of mass in the form of solid precipitation to lesser extent. The studies carried in North America, show that some glaciated regions have positive correlation between temperature and snowfall and in some regions snowfall and temperature is negatively correlated (Karl et al., 1993) [13]. Therefore the changes of snow cover are uncertain and much depends on meteorological parameters which require in-depth investigations. It is often argued that variability in mass balance of maritime glaciers is dominated by winter season precipitation, while continental glaciers like in Drass valley are most strongly influenced by change in temperature during summer season too (Mayer et al., 2006; Ohmura et al., 1992) [14] [15]. The movement of mid latitude westerly flow across the Himalaya particularly West Himalaya during winter and pre monsoon cause precipitation in higher reaches in the form of snow and plays very crucial role in accumulation of snow over different glaciers. Studies been investigated to assess the role of meteorological parameters in governing the snow cover extent and it has been found that annual change in glacier extent is due wintertime anomalies in accumulated snow and maximum temperature anomalies in summer. Investigations carried to study relationship between snowfall and temperature of Drass valley a record of 28 yrs to assess seasonal change, if any in mean maximum and mean minimum temperature along with precipitation.

\subsection{Temperature}

Temperature time series at Drass Valley Station (1987-2013) been used to provide a regional picture of seasonal and year-to-year variation in temperature and glacier mass extent at higher altitude. Over a record period of 28 years, there has been a small increase in annual mean temperature at Drass of $-0.426^{\circ} \mathrm{C}$ per decade prior to 1995 . However, since 1996 the rate of increase has accelerated to $0.375^{\circ} \mathrm{C}$ per decade. If individual month of season are further examined then large significant increase in mean temperature are seen during the winter season particularly November to June, a possible signal of seasonal shift of winter to June.

The mean monthly maximum summer temperature for time series 1987-2001, 2001-2008 and 2008-2013 is to provide a regional picture of seasonal and year-to-year variation in temperature (Figure 2). The mean monthly maximum summer temperature from June, July, August, and September is $16.2^{\circ} \mathrm{C}, 20.8^{\circ} \mathrm{C}, 17.7^{\circ} \mathrm{C}$ and $11.7^{\circ} \mathrm{C}$, respectively for the years $1987-2001$, as compared to $20.6^{\circ} \mathrm{C}, 23.7^{\circ} \mathrm{C}, 23.6^{\circ} \mathrm{C}$ and $20.4^{\circ} \mathrm{C}$ for the years $2001-$ 2008 and $14.9^{\circ} \mathrm{C}, 17.22^{\circ} \mathrm{C}, 15.17^{\circ} \mathrm{C}$ and $10.82^{\circ} \mathrm{C}$ for the years 2008-2013. During summer season, particularly, in July and August highest temperature ranged between $26.2^{\circ} \mathrm{C}$ and $25.3^{\circ} \mathrm{C}$ in the years, 2001-2008 and 19872001 respectively as compared to $12.1^{\circ} \mathrm{C}$ and $13.7^{\circ} \mathrm{C}$ during $2008-2013$ respectively. The degree variation of standard deviation of mean maximum temperature during summer months ranged between $5.18^{\circ} \mathrm{C}-1.85^{\circ} \mathrm{C}$, $3.6^{\circ} \mathrm{C}-0.911^{\circ} \mathrm{C}$, and $1.3^{\circ} \mathrm{C}-0.22^{\circ} \mathrm{C}$ (Figure 2) during 1987-2001, 2001-2008 and 2008-2013, respectively 


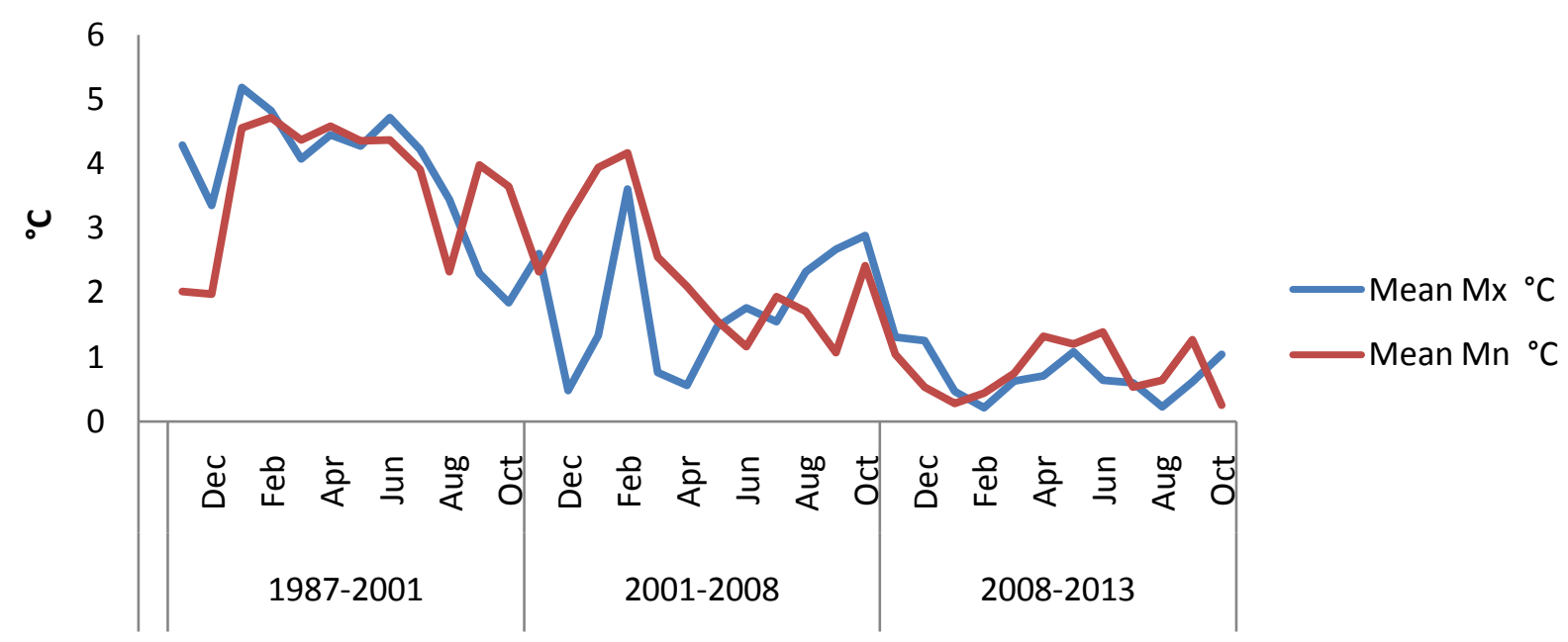

Figure 2. Drass: mean maximum and mean minimum temperature (STDEV) 1987-2013.

indicating higher range of dispersion in maximum temperature during 1987-2001 in comparison to 2008-2013.

The mean minimum temperature during winter season (November, December, January, February, March, April, and May) ranged between $-3.635^{\circ} \mathrm{C}$ to $-22.45^{\circ} \mathrm{C},-1^{\circ} \mathrm{C}$ to $-19.33^{\circ} \mathrm{C}$ and $-9.48^{\circ} \mathrm{C}$ to $1.02^{\circ} \mathrm{C}$ respectively for the time series 1987-2001, 2001-2008 and 2008-2013 respectively, showing degree variation of standard deviation of $1.98-4.71^{\circ} \mathrm{C}, 1.57^{\circ} \mathrm{C}-4.17^{\circ} \mathrm{C}$ and $0.28^{\circ} \mathrm{C}-1.39^{\circ} \mathrm{C}$ (Figure 2). The lowest minimum temperature during winter season recorded in January and February is $-34^{\circ} \mathrm{C}$ and $-27^{\circ} \mathrm{C}$ in $1989-2001$ and $2001-2008$ respectively as compared to $-13.4^{\circ} \mathrm{C}$ and $-10.7^{\circ} \mathrm{C}$ during the time series $2008-2013$.

The monthly diurnal temperature range for winter and summer season (Figure 3) shows an increasing trend during 1987-2001 and 2001-2013 and the average winter diurnal is $14.9,11.3^{\circ} \mathrm{C}$, summer diurnal 14.98 , and $11.576^{\circ} \mathrm{C}$ respectively for the time series. The highest diurnal range in 1987-2001 and 2001-2013 during winter is February $18.8^{\circ} \mathrm{C}$ and $12.8^{\circ} \mathrm{C}$ and in summer, July $16.48^{\circ} \mathrm{C}$ and $12.04^{\circ} \mathrm{C}$ respectively.

\subsection{Precipitation}

Drass glacier valley receives precipitation in the form of snowfall during winter season due to Western Disturbances and rainfall during summer season due to Westerly's and Southern Jet stream Movements. Most of the precipitation in the higher reaches above the snout is in the form of snowfall, both during summer and winter seasons.

The analysis of average daily precipitation of Drass (rainfall and snowfall) from the last fortnight of October to last fortnight of May varies from $239 \mathrm{~cm}$ (1996-1997) to $968 \mathrm{~cm}$ (2004-2005, 2010-2011) (Figure 4(a)). The average highest precipitation (snowfall) for the years 1995-1996, 2001-2002, 2003-2004, and 2004-2005, 2011-2012 was recorded above $500 \mathrm{~cm}$; the moderate snowfall of $300-400 \mathrm{~cm}$ has been recorded during the seasonal years of 1997-1998, 1998-1999 and 2012-2014. The low snowfall of less than $300 \mathrm{~cm}$ during 19911997, 1999-2000 and 2000-2001, reveals 1991 to 2001 was dry decade for the region. Summers (May-October) were dry and nearly devoid any precipitation during the period 1987 to 2001. However, during this period, the highest snowfall of $840 \mathrm{~cm}$ was anomaly during 1989-1990 and 1991-1992 in 54 falls with major water equivalent of $9415.5 \mathrm{~mm}$. The overall weather scenario changed from the year 2002 onwards due influence of wet spells during the summers. The 2009-2012, and 2002-2003 recorded high snowfall of about $378 \mathrm{~cm}$ recorded in 50 falls with total water equivalent of $422 \mathrm{~mm}$ (Figure 4(b)). The pattern of snowfall varies on monthly and yearly basis $420 \mathrm{~cm}$ ( $405 \mathrm{~mm}$ w.e.v.) of snowfall took place between the months of November and May and the rest (186 cm - $171.2 \mathrm{~mm}$ w.e.v.) between the months of June and September. During 2010-2013, the average precipitation was above the normal as summers too were wettest. In 2014, maximum precipitation was recorded in June and July. On the glacier body, nearly $72 \%$ of solid precipitation recorded is during the winter season October to May and only $28 \%$ of snowfall takes place during summer season.

The analysis of daily precipitation from first fortnight of November 1995 to last fortnight of October 2001varies from $984 \mathrm{~mm}$ to $171.6 \mathrm{~mm}$ in water equivalent in comparison $979.9 \mathrm{mn}$ to $219 \mathrm{~mm}$ w.e.v. during 


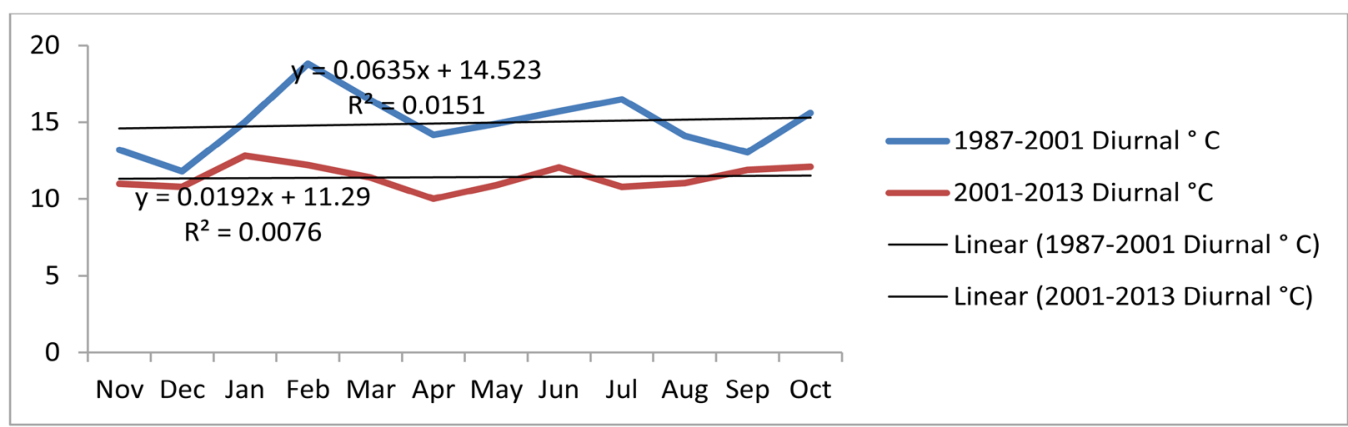

Figure 3. Drass: diurnal temperature of maximum and minimum (1987-2013).

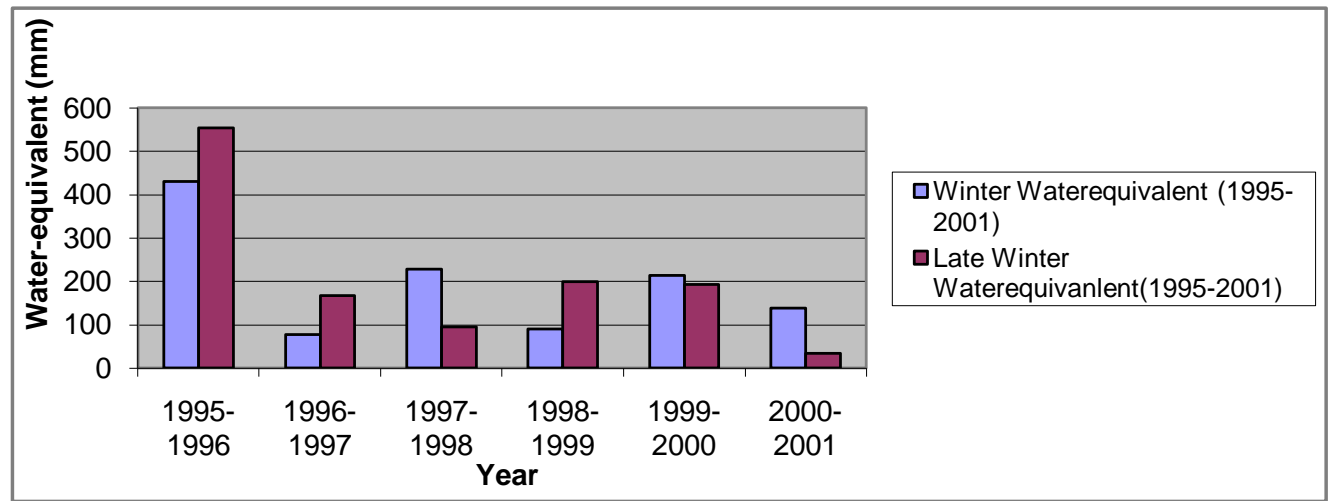

(a)

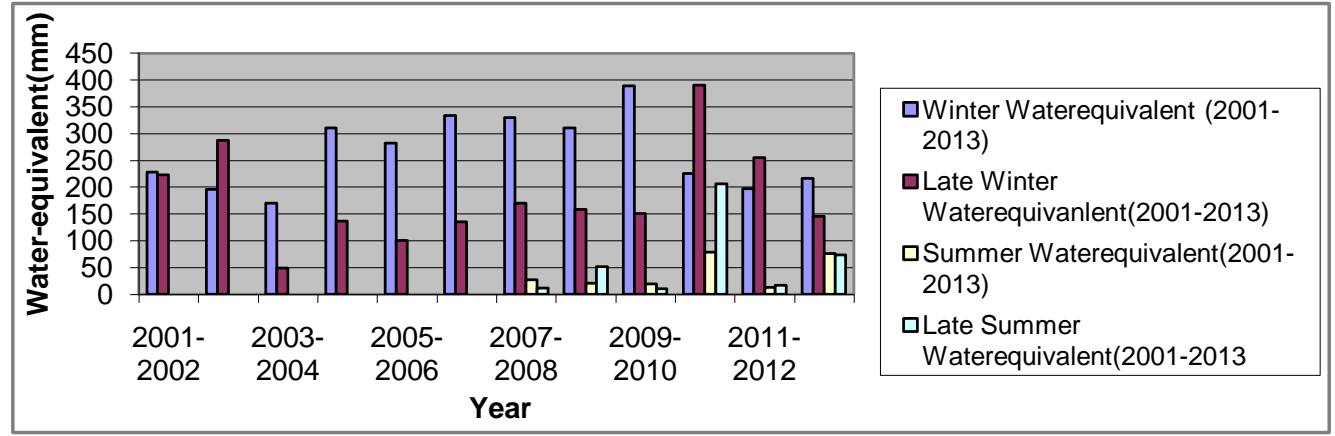

(b)

Figure 4. (a) Drass: winter precipitation in water-equivalent 1995-2001; (b) Drass: seasonal (winter and summer) precipitation in water-equivalent 2001-2013.

years 2001-2013 (Figure 4(a) and Figure 4(b)). Out of total precipitation, highest contribution (above $500 \mathrm{~mm}$ w.e.v.) of snowfall is, $984 \mathrm{~mm}$ (1995-96), $979.5 \mathrm{~mm}$ (2010-11), $565 \mathrm{~mm}, 562 \mathrm{~mm}, 589.1 \mathrm{~mm}, 495 \mathrm{~mm}$ and $587.3 \mathrm{~mm}$ w.e.v. (2007-2012), moderate, (300 - $450 \mathrm{~mm}$ w.e.v.) of snowfall recorded during the seasonal years of 2001-2007 and 2012-2014 and low snowfall of less than $300 \mathrm{~cm}$ during 1991-95, 1997-98, 1999-2000, and 2000-2001, respectively revealing 1991 to 2001 a dry decade with exceptional anomaly of 1995-96. The pattern in annual, seasonal and monthly mean snowfall investigated for the time series 1995-2001, show $196 \mathrm{~mm}$ w.e.v. of snow took place between months of November and March (winter) and $206.8 \mathrm{~mm}$ w.e.v. of snow between March and May (late winter) suggesting that about 52\% of snowfall took place in late part of winter. Similarly, during the period 2001-2007, $253.4 \mathrm{~mm}$ of water equivalent of snowfall took place in winter season (November, December-previous year, and January-February-current year) and $155.48 \mathrm{~mm}$ w.e.v. of snowfall of late winter (March-May) reveals that 38\% snowfall took place late winter (Figure 5). During 2008-2013, 278 mm w.e.v. of snowfall in winter season (November and March), $211.67 \mathrm{~mm}$ w.e.v. of snowfall in late winter (March to May), 


\section{Distribution of Snowfall in water- equivalent} (mm) of Drass 2002-2013

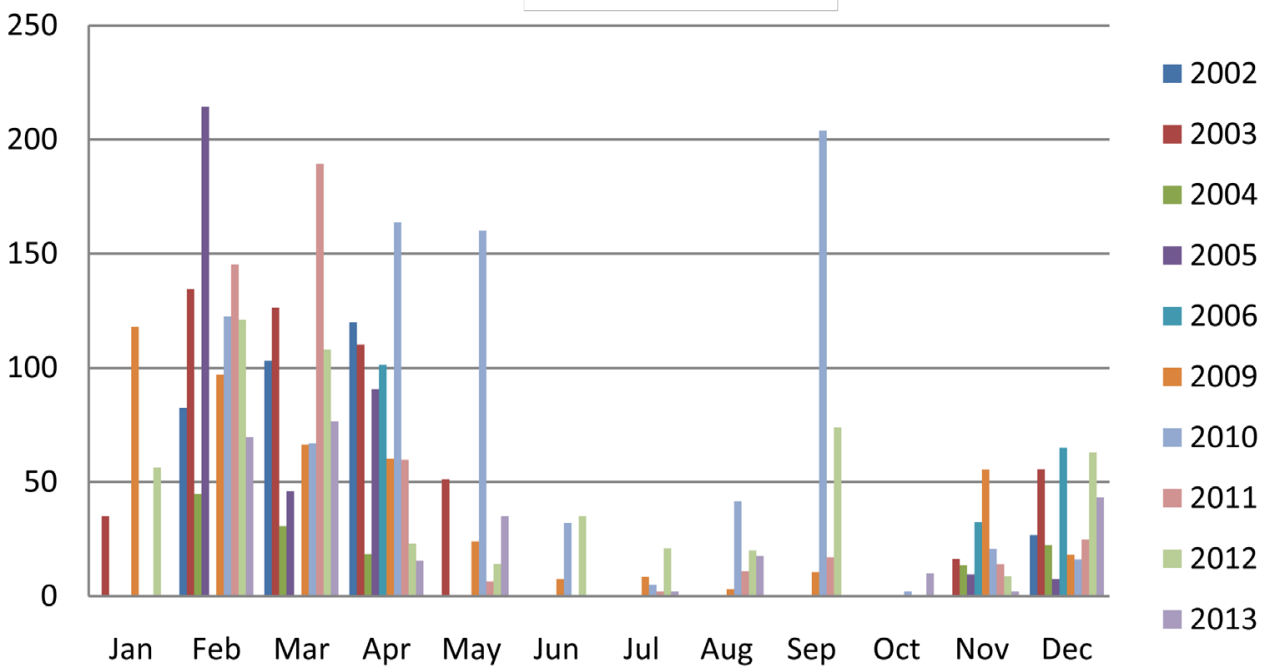

\section{Distribution of Snowfall in water- equivalent (mm) of Drass 1995-2001}

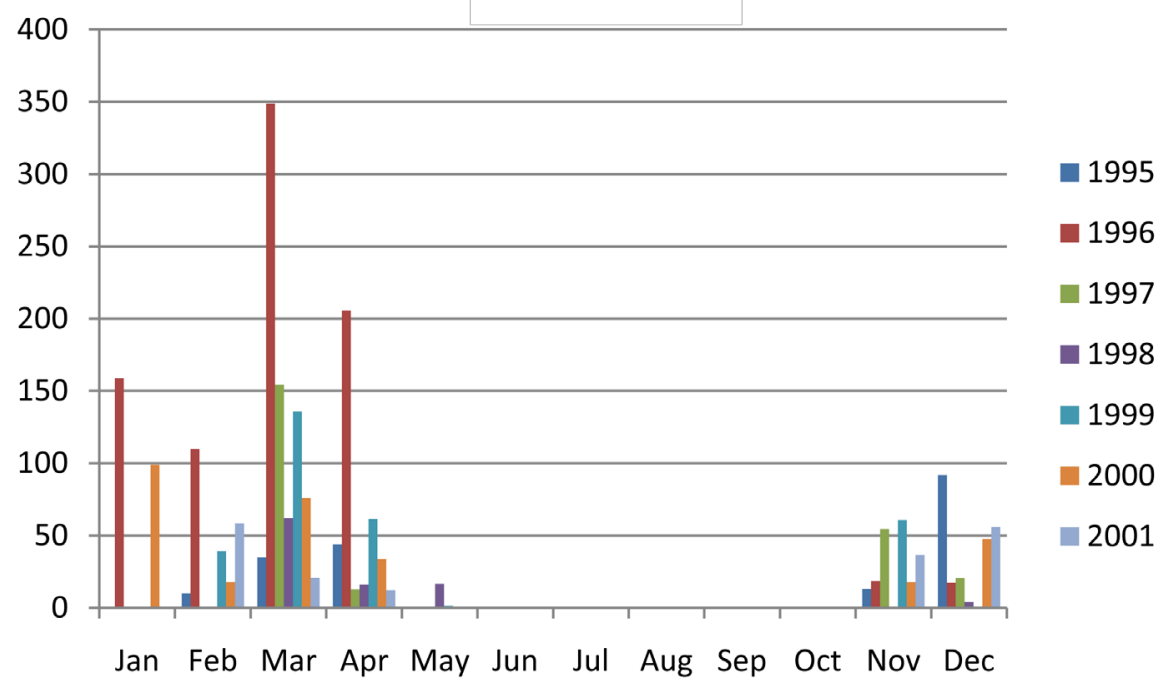

Figure 5. Monthly distribution of snowfall (water equivalent), Drass 1995-2013.

and $100.71 \mathrm{~mm}$ w.e.v. of precipitation in summer (June-September) suggesting that 37.5\% snowfall took place late winter and $17 \%$ precipitation in summer season (June-September) (Figure 5). Heavy snowfall in later part of winter and summer holds considerable significance in terms of health of glacier and helps in consolidating ice, reducing ambient temperature and degree-day melting that results positive impact on glacier stability and growth.

Analysis of rainfall records shows that Drass station experienced overall dry spells during the summer periods of 1995-2002. The rainfall scenario in summer period initiated a change in year 2002-03 latter as regular phenomenon since 2005-06. The total rainfall/snowfall record for the years 2011, 2012, 2013, 2014 from May to 
September is 42.0, 56.2, 90.1, $146.1 \mathrm{~mm}$ in water equivalent respectively (Figure 5). Whereas the analysis of precipitation recorded at the glacier, base camp and at equilibrium line reveal that rainfall occurs at lower elevation in the vicinity of glacier snout and snowfall at higher elevation (near equilibrium line of glacier).

\subsection{Analysis of Temporal Temperature and Precipitation Change}

The trends in annual, seasonal and monthly mean temperature and precipitation (snow fall) were investigated for Drass glacier basin from 1988 to 2013. The records have been analyzed by fitting linear least square trend line to assess the behaviour of temperature and precipitation. The analysis reveals that mean maximum temperature (1987-2000) shows no change in trend line during winter as well late winter season (Figure 6(b)) compared to mean minimum winter season(November-March) showing marginal change in temperature in relation to late winter (March-May) showing increasing trend in temperature (Figure 6(a)). Similarly mean maximum temperature (2001-2013) trend line shows decreasing trend during summer (June-August) as well late summer (September-October) season, thereby indicating cooling, hence reducing degree-day melting of glaciers (Figure 6(d)). The trend line of mean minimum temperature however shows marginal change in its behaviour (Figure 6(c)).

The trends in diurnal temperature change shows increasing trend in 1987-2000 and 2001-2013 in summer as well winter that substantiate that late winter warming leading to sublimation of ice from glacier body triggering the influence of precipitation during summer 2005-2013.

The role of temperature and precipitation have been examined in governing glacier cover extent in Drass valley and found that negative correlation $(-0.471,-0.145)$ between mean minimum temperature and snowfall in 1995-2000, in comparison to weak positive correlation (0.191) during winter season of 2000-2013 time series, is insignificant as per "P" test values (Table 1). The temperature and precipitation analysis and their trend shows an interesting shift of peak summers and winter season until late summer (August, September) and late winter (March to June), this shift has helped the overall health of glaciers and their stabilization process.

Shows a declining trend during June, to October from 2006 onwards. The decreasing trend thereby indicates cool summers and appreciable cooling during the late summer season particularly from July to September (2009-2013) (Figure 2 and Figure 3). It results in slow melting of glaciers and growth of permafrost condition in higher reaches. The trends in monthly mean maximum and minimum temperature during October to May indicate an increasing trend in maximum temperature and marginal decreasing trend in minimum temperature

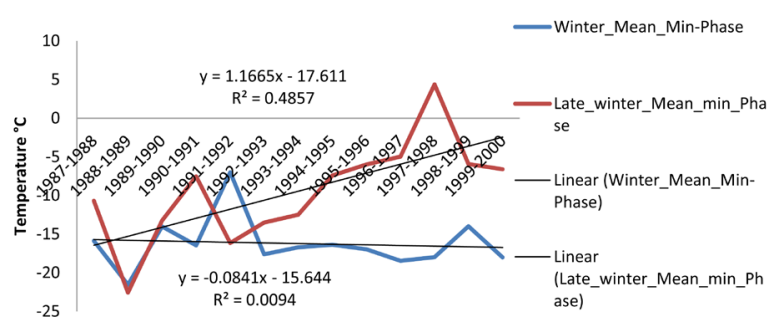

(a)

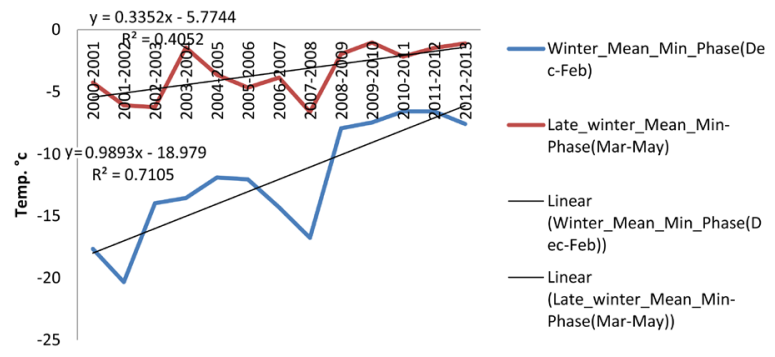

(c)
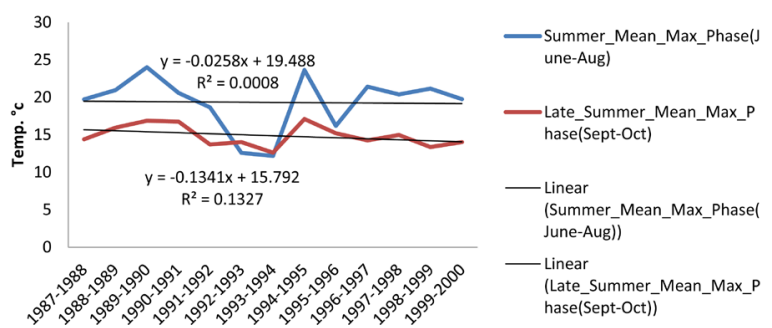

(b)

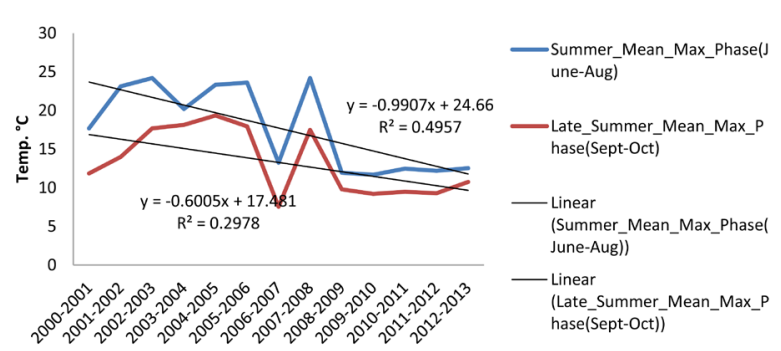

(d)

Figure 6. (a) Drass: mean-min. temperature winter season 1987-2000 (trend line); (b) Drass: mean-max. temperature summer season 1987-2000 (trend line); (c) Drass: mean-min. temperature winter season 2000-2013 (trend line); (d) Drass: mean-max. temperature summer season 2000-2013 (trend line). 
Table 1. Correlation coefficient of temperature and solid precipitation (water equivalent) of Drass (1995-2013).

\begin{tabular}{|c|c|c|c|c|}
\hline & $\begin{array}{l}\text { Correlation Results of Seasonal Monthly Temperature } \\
\text { and Precipitation of Drass (1995-2013) }\end{array}$ & Correlation & p-Value & Significance \\
\hline \multirow{4}{*}{ Winter } & $\begin{array}{l}\text { Winter Mean Min. Temperature and Precipitation } \\
\text { (water equivalent) 1995-2000 (Dec-Feb) }\end{array}$ & -0.18 & 0.772 & No \\
\hline & $\begin{array}{l}\text { Winter Mean Min. Temperature and Precipitation } \\
\text { (water equivalent) 2000-2013 (Dec-Feb) }\end{array}$ & 0.191 & 0.533 & No \\
\hline & $\begin{array}{l}\text { Late Winter Mean Min. Temperature and Precipitation } \\
\text { (water equivalent) 1995-2000 (Mar-May) }\end{array}$ & -0.474 & 0.42 & No \\
\hline & $\begin{array}{l}\text { Late Winter Mean Min. Temperature and Precipitation } \\
\text { (water equivalent) 2000-2013 (Mar-may) }\end{array}$ & -0.69 & 0.822 & No \\
\hline Summer & $\begin{array}{l}\text { Summer Mean Max. Temperature and Precipitation } \\
\text { (water equivalent) 2007-2013 (June-Aug) }\end{array}$ & -0.145 & 0.784 & No \\
\hline
\end{tabular}

resulting in warmer winters (November to May) with a small change in minimum temperature (Figure 2 and Figure 3). The trends in diurnal variation during the summer season also indicate a decreasing trend that also substantiates the late winter warming leading to sublimation of ice from the glacier body that has helped increasing trend in late winter (June to September) precipitation and corroborates with the increasing precipitation trend during the season.

Snowfall pattern reveal increasing trend in September-October, February-May, and June, that helps in the growth and development of the glacier. The micro-meteorological data from 2011-2014 has served as tool to correlate different meteorological parameters with mass balance inputs and equilibrium line altitude to assess the fluctuation record on the Machoi glacier body. The temperature analysis and their trend shows an interesting shift of peak summers and winter season till late summer (August, September) and late winter (March to June).

\section{Glacier Inventory}

The glacier inventory is prepared from the available seven Survey of India topographical sheets document nearly 115 glaciers in Drass valley basin confined between altitudes $3600 \mathrm{~m}$ to $6000 \mathrm{~m}$. Out of these, 81 glaciers (more than $0.1 \mathrm{~km}^{2}$ ) selected are for detailed comparative study. Thirty seven glaciers are more than $1 \mathrm{~km}^{2} .16 .7 \%$ of glaciers are $>3 \mathrm{~km}^{2}, 4.2 \%$ of the total glaciers are between the area of $3 \mathrm{~km}^{2}$ and $6 \mathrm{~km}^{2}, 5.8 \%$ of total glaciers are between $6 \mathrm{~km}^{2}$ and $9 \mathrm{~km}^{2}, 1.7 \%$ of total glaciers are between $9 \mathrm{~km}^{2}$ and $12 \mathrm{~km}^{2}$ and $2.5 \%$ total glaciers are < $12 \mathrm{~km}^{2}$. The largest glacier in the basin has area of $15.14 \mathrm{~km}^{2}$. This clearly suggests that Drass basin is occupied by large number of small glaciers and niche glaciers. The glaciers in Drass basin are distributed more or less equally in all directions and do show preferred orientation to north, northeast, and northwest (66\%). A good number of glaciers are orientated in north east (21 no's) and north-west (19 no's), north (14 no's), east (9 no's), cover total glacier area of $187.9 \mathrm{~km}$. However, as per the satellite data of year 2001 and 2013, the total number of glaciers has increased to 150 in number. The change in areal extent in glacier area has decreased from 187.9 $\mathrm{km}^{2}$ to $158.42 \mathrm{~km}^{2}$ and $156.65 \mathrm{~km}^{2}$ during the period 1965, 2001, and 2013 respectively. Satellite data have been used as base of comparison for their detail study, in order to assess the behaviour of the Drass glaciers during current times (2001-2013) and in the early past (1965-2001). In addition, to study causative factors responsible for changes in behaviour of glaciers in Drass valley.

\section{Monitoring of Current Behaviour Glaciers (2001 and 2013)}

To assess current behaviour of the glaciers the IRS-LISS-III images of 2001 and 2013 visually interpreted to demarcate the boundaries of 150 glaciers of Drass valley. The various digital image-processing techniques are applied to supplement it with ground truth data in satellite image of 2013 for accurate identification of snout position and to assess change in area of all the glaciers.

\section{Steady State Phase in Glacier Area and Snout Position}

The study shows that 120 glaciers of different dimensions do not show any change in their area between the pe- 
riods 2001 and 2013. 98 glaciers are less than $1 \mathrm{~km}^{2}$, 19 glaciers $1 \mathrm{~km}^{2}-3 \mathrm{~km}^{2}$, and one glacier is more than 10 $\mathrm{km}^{2}$ area. The glaciers of these categories are distributed in more or less in all direction with large percentage (61.2\%) are oriented north words with fare percentage oriented NW (21\%), N and NE (20\%).

The remaining 30 glaciers show marginal change in area, length, as per satellite imageries of 2001 and 2013. Twenty eight glaciers out of 30 glaciers show vacation of area from 2001 to 2013. The dominant orientation in this category is in north west (41\%), north east and north (18.75\% each). 18 glaciers have loss less than 0.05 $\mathrm{km}^{2}$ area, 6 glaciers $0.05 \mathrm{~km}^{2}-0.1 \mathrm{~km}^{2}$, two glaciers $0.1 \mathrm{~km}^{2}-0.2 \mathrm{~km}^{2}$ and two glaciers vacated above $0.2 \mathrm{~km}^{2}$ area, Interestingly, the glacier ID No. 43 N/7-139 and 43 N/11-150 shows gain in area by 30\% and 40\% respectively from 2001 to 2013 the snout of the glaciers are confined in northwest and east direction (Table 2).

The constant shift in the altitudinal position of three main classes of glaciers based on area $0-2 \mathrm{~km}^{2}, 2-5$ $\mathrm{km}^{2}$ and above $5 \mathrm{~km}^{2}$, show that larger glaciers above $5 \mathrm{~km}^{2}$ has vacated a small area $(0.64 \%$ to $2.64 \%$ of glacier area) in comparison to small glacier ranging in area $2 \mathrm{~km}^{2}$ to $5 \mathrm{~km}^{2}$ (1.68\% to $9 \%$ of glacier) during 12 years period. There by indicating that glaciers of Drass valley in general retreat at slow pace (Figure 7).

\section{Long-Term Monitoring of Glaciers between 1965 and 2001}

Eighty-one glaciers of Drass valley identified for long-term monitoring for the period 1965-2001 and 2001-2013. In-homogeneity in glacier area change shows ten glaciers experienced gain in area, 13 glaciers a loss more than $50 \%$ of its area, 18 glaciers lost $25 \%$ - 50\% of glacier area and the remaining glaciers lost marginal area during last 50 years period. Due to in-homogeneity in glacier area and observation period, we evaluated the changes in glacier areas on yearly basis. Five glaciers vacated at the rate of $>10,000 \mathrm{~m}^{2} / \mathrm{yr}$, 5glaciers vacated at rate 5000 $\mathrm{m}^{2}-10,000 \mathrm{~m}^{2} / \mathrm{yr}, 9$ glaciers vacated $2500 \mathrm{~m}^{2}-5000 \mathrm{~m}^{2} / \mathrm{yr}$ and remaining glaciers lost $15 \mathrm{~m}^{2}-1500 \mathrm{~m}^{2} / \mathrm{yr}$. This indicates that majority of glaciers in Drass basin are small and niche ones confined in higher altitude affected by solar radiation melting. The yearly change in area of each glacier ranges $0.12 \%$ to $1.7 \%$ of glacier area (Figure 8).

\subsection{Changes in Glacier Area from 1965-2001 and 2001-2013}

Ten glaciers out of eighty-one glaciers show gain in area during last three and half decade (Table 1). The dominating percentage of these glaciers are oriented in northwest and northeast (30\% each) followed by southeast (20\%), southwest and east (10\% each). The snout of glaciers oriented in northwest show increase in length as well the area by $26.5 \%$ to $15 \%$ of the glaciers such as the glacier ID. Nos. 43 N15-03 $\left(0.5 \mathrm{~km}^{2}\right), 43$ N15-04 $\left(0.41 \mathrm{~km}^{2}\right)$ and $43 \mathrm{~N} 11-13\left(0.03 \mathrm{~km}^{2}\right)$ respectively. The glaciers in northeast direction show increase in area by 9.5\% such as glacier id No. 43N11-42, 43N07-64 (Figure 7 and Figure 8).

Table 2. Glaciers showing gaining in area (2001-2013).

\begin{tabular}{ccccc}
\hline Glaciers Id & Orientation & Area 2013 & Area 2001 & Change in Area \\
\hline 43 N07 139 & SW & 0.26 & 0.2 & -0.06 \\
43 N11 150 & E & 0.07 & 0.05 & -0.02 \\
\hline
\end{tabular}

\section{change in area}

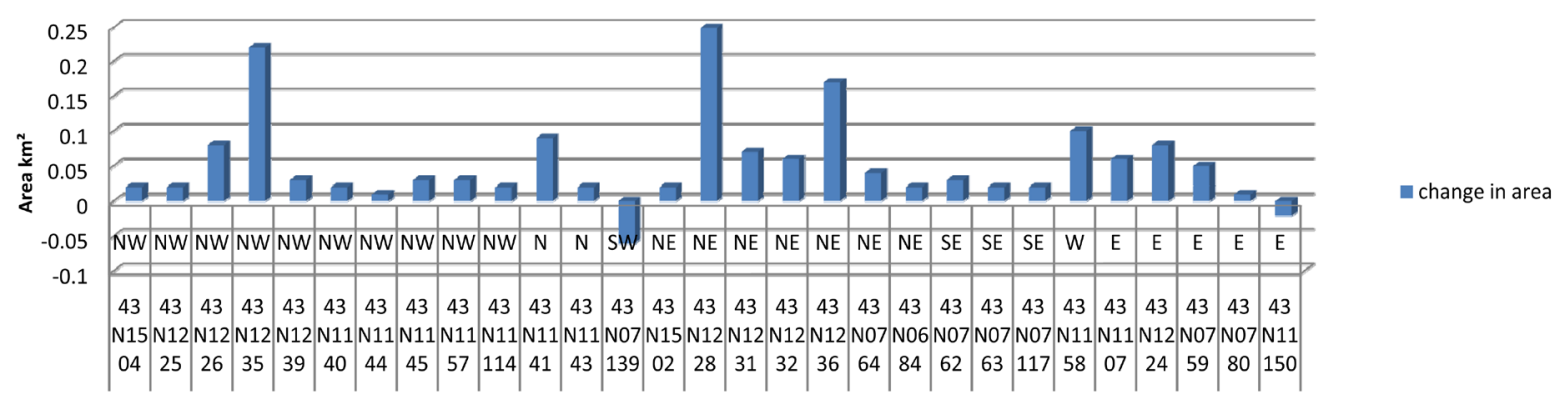

Figure 7. Glaciers in Drass valley showing changes in area 2001-2013. 


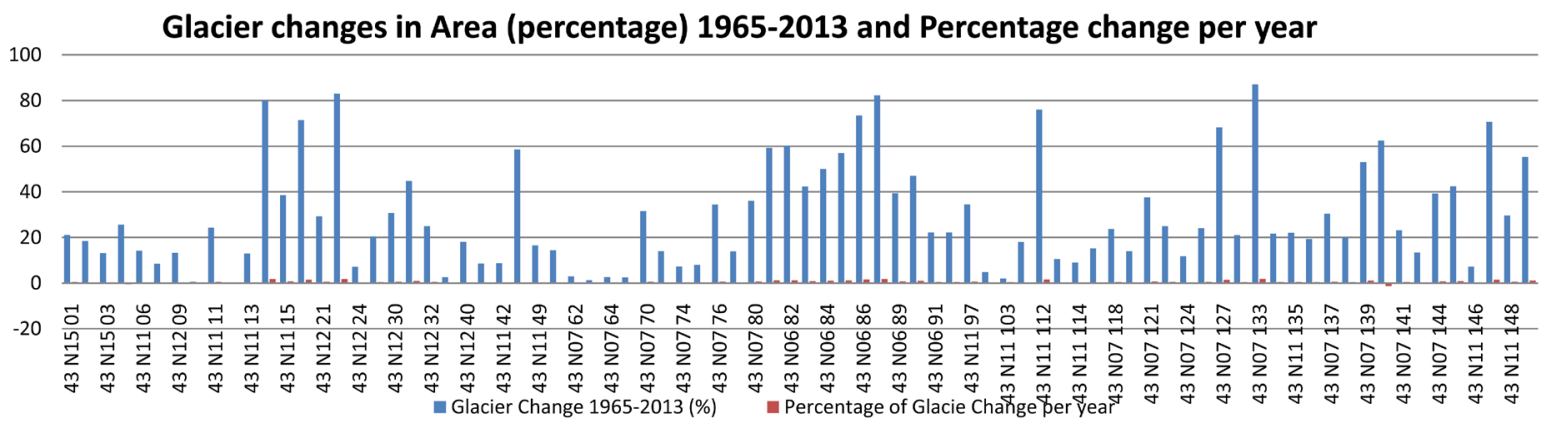

Glaciers change in area $\mathrm{m}^{2} /$ year of Drass Basin (1965-2013)

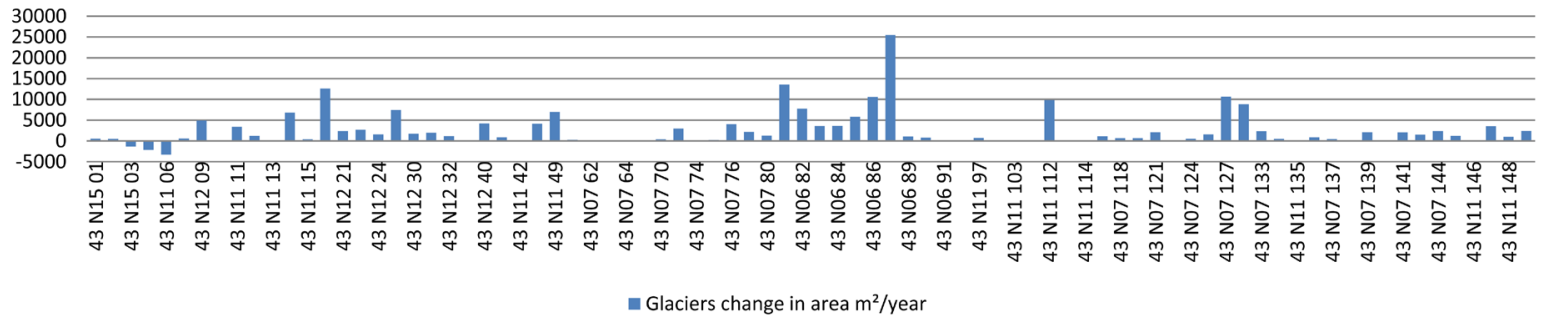

Figure 8. Glaciers in Drass valley showing change in area (1965-2013).

Out of the ten glaciers, four glaciers with id. No. 43 N15-04, 43 N07-62, 63, 64, show gain in area during 1965 to 2001 but loss in area from 2001 to 2013 and remaining six glaciers of the category show gain in area from 1965 to 2001, and no change in their area between 2001 and 2013 (Table 2 and Table 3).

\subsection{Relative Change of Snout Position of Large Glaciers from 1965 to 2001}

Eleven large glaciers show considerable shift of its snout position during the period 1965 and 2001 there by showing decrease in length as well the area of glacier. Four glaciers such as id No. 43 N12-28, 43 N12-40, 43

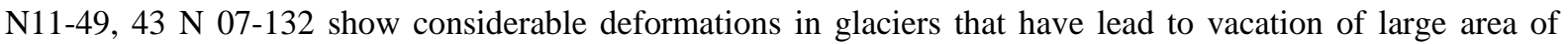
glaciers, to the extent of above $15 \%-21 \%$ of a glacier area loss. Similarly, in case four glaciers id No $43 \mathrm{~N}$

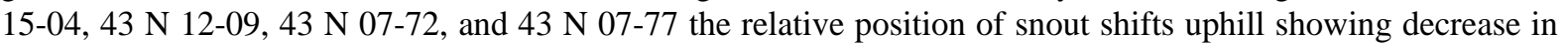
maximum length of glacier, and moderate decrease in area (10\% to $15 \%$ of glacier area). However three glaciers id No. 43 N 12-24, 43 N 12-36, and 43 N 11-41 show very small shift in glacier snout as well in glacier area (less than $10 \%)$.

The overall vacation of area of 11 large glaciers from 1965 to 2001 show that one glacier shrunk the area at the rate of $25,000 \mathrm{~m}^{2} / \mathrm{yr}$, four glaciers vacated the area at the rate of $10,023 \mathrm{~m}^{2} /$ year, three glaciers vacated area at the rate of $3920 \mathrm{~m}^{2} /$ year and three at rate of $1478 \mathrm{~m}^{2} /$ year (Figure 6 and Table 4). Further 13 large glaciers of different dimensions have fragmented in to nearly 30 glaciers during 1965 to 2001 but do not show any appreciable change in reduction of area as well maximum length of glaciers.

\section{Discussion and Conclusion}

Drass valley houses presently 150 glaciers as per satellite data of 2001 and 2013, whereas as per 1965 SOI topographic sheets, the basin occupied nearly 115 glaciers. The increased number in glaciers (115 to 151 glaciers) is due to fragmentation of 13 large glaciers of 1965 into smaller ones and development of new glaciers. Eighty one glaciers having more than $0.1 \mathrm{~km}^{2}$ areas being selected from Survey of India topographical sheets for comparative analysis for different time periods, are monitored to assess long-term and short-term changes if any to assess the health of glaciers in general particularly in context of current stability of glaciers.

The monitoring of 150 glaciers Drass sub basin suggests that 120 glaciers do not show any change in their area, 2 glaciers show gain in area and 28 glaciers lose in glacier area. The snout of majority of large glaciers is facing northeast, northwest and east (67\% of 30 glaciers). The long-term monitoring of Drass glaciers shows 
Table 3. Glaciers showing gaining in area (1965-2001).

\begin{tabular}{ccccc}
\hline Glaciers Id & Orientation & Area 2001 & Area 1965 & Change in Area \\
\hline 43 N15 03 & NW & 3.83 & 3.33 & -0.5 \\
43 N15 04 & NW & 1.96 & 1.55 & -0.41 \\
43 N11 13 & N & 0.23 & 0.2 & -0.03 \\
43 N11 42 & NE & 0.23 & 0.21 & -0.02 \\
43 N07 62 & SE & 0.7 & 0.68 & -0.02 \\
43 N07 63 & SE & 1.56 & 1.54 & -0.02 \\
43 N07 64 & NE & 4.01 & 3.68 & -0.33 \\
43 N11 102 & NE & 0.42 & 0.4 & -0.02 \\
43 N11 113 & E & 0.19 & 0.17 & -0.02 \\
43 N07 140 & SW & 0.17 & 0.16 & -0.01 \\
\hline
\end{tabular}

Table 4. Relative changes in attitudinal position of snout and maximum length and area of glaciers in 1965 and 2001.

\begin{tabular}{|c|c|c|c|c|c|c|c|c|c|c|}
\hline \multirow[b]{2}{*}{ Glaciers Id } & \multirow[b]{2}{*}{ Orientation } & \multirow{2}{*}{$\begin{array}{c}\text { Altitude of } \\
\text { Snout of } \\
\text { Position (2001) }\end{array}$} & \multirow[b]{2}{*}{$\begin{array}{l}\text { Area } \\
2001\end{array}$} & \multirow{2}{*}{$\begin{array}{c}\text { Altitude of } \\
\text { Snout of } \\
\text { Position } \\
\text { (1965) }\end{array}$} & \multirow[b]{2}{*}{$\begin{array}{l}\text { Area } \\
1965\end{array}$} & \multirow[b]{2}{*}{$\begin{array}{c}\text { Change in } \\
\text { Area }\end{array}$} & \multicolumn{2}{|c|}{2001} & \multicolumn{2}{|c|}{1965} \\
\hline & & & & & & & $\begin{array}{c}\text { Length } \\
(\mathbf{k m})\end{array}$ & $\begin{array}{c}\text { Width } \\
\text { (km) }\end{array}$ & $\begin{array}{c}\text { Length } \\
(\mathbf{k m})\end{array}$ & $\begin{array}{c}\text { Width } \\
\text { (km) }\end{array}$ \\
\hline 43 N15 03 & NW & $3990 \mathrm{~m}$ & 3.83 & $3880 \mathrm{~m}$ & 3.33 & -0.5 & 5.2 & 0.6 & 6.4 & 0.3 \\
\hline 43 N15 04 & NW & $4520 \mathrm{~m}$ & 1.96 & $3990 \mathrm{~m}$ & 1.55 & -0.41 & 2.6 & 0.5 & 3.1 & 0.3 \\
\hline 43 N11 13 & $\mathrm{~N}$ & $4760 \mathrm{~m}$ & 0.23 & $4710 \mathrm{~m}$ & 0.2 & -0.03 & 0.8 & 0.4 & 1 & 0.1 \\
\hline 43 N11 42 & $\mathrm{NE}$ & $4600 \mathrm{~m}$ & 0.23 & $4590 \mathrm{~m}$ & 0.21 & -0.02 & 0.9 & 0.3 & 0.8 & 0.2 \\
\hline 43 N07 62 & SE & $4520 \mathrm{~m}$ & 0.7 & $4540 \mathrm{~m}$ & 0.68 & -0.02 & 1.3 & 0.8 & 1.2 & 0.7 \\
\hline 43 N07 63 & SE & $4420 \mathrm{~m}$ & 1.56 & $4400 \mathrm{~m}$ & 1.54 & -0.02 & 1.7 & 1.2 & 1.8 & 1.1 \\
\hline 43 N07 64 & $\mathrm{NE}$ & $3830 \mathrm{~m}$ & 4.01 & $3790 \mathrm{~m}$ & 3.68 & -0.33 & $2.0,3.6$ & 0.8 & $1.9,3.1$ & 0.8 \\
\hline 43 N11 102 & $\mathrm{NE}$ & $4580 \mathrm{~m}$ & 0.42 & $4600 \mathrm{~m}$ & 0.4 & -0.02 & 1.1 & 0.4 & 1 & 0.5 \\
\hline 43 N11 113 & E & $4760 \mathrm{~m}$ & 0.19 & $4740 \mathrm{~m}$ & 0.17 & -0.02 & 0.7 & 0.4 & 0.7 & 0.3 \\
\hline 43 N07 140 & SW & $4740 \mathrm{~m}$ & 0.17 & $4720 \mathrm{~m}$ & 0.16 & -0.01 & 0.7 & 0.3 & 0.5 & 0.4 \\
\hline
\end{tabular}

decrease in area from $187.9 \mathrm{~km}^{2}$ (1965), to $158.42 \mathrm{~km}^{2}$ (2001) and further to $156.65 \mathrm{~km}^{2}$ (2013). The glaciers have vacated maximum area $\left(28.48 \mathrm{~km}^{2}\right)$ between 1965 and 2001 in comparison to $1.77 \mathrm{~km}^{2}$ between 2001 and 2013. Thus overall glacier area loss in Drass basin glaciers per year is $0.813 \mathrm{~km}^{2}$ (1965-2001), and for 11 individual large glaciers in the basin, the loss is between $5423 \mathrm{~m}^{2}$ and $1473 \mathrm{~m}^{2}$. Similarly snout of the glacier facing N, NW did not show any change area between 1969 and 2001. During 2001-2013, glacier vacated the $0.136 \mathrm{~km}^{2}$ area per year and $80 \%$ glaciers do not show any change area and are in stable mode.

Over a record period of 28 years, there has been a small increase in annual mean temperature at Drass of $-0.426^{\circ} \mathrm{C}$ per decade prior to year 1995 . However, since 1996 the rate of increase has accelerated to $0.375^{\circ} \mathrm{C}$ per decade. The analysis of mean monthly temperature (Maximum and Minimum) trendline for period 28 years was lack of fit of lower portion of data (1988-2000) to upper portion of data (2001-2013); hence it is attributed to phase transition threshold. It indicates that winter is cooler, late winter warm humid, and summer cool and wet during time series 2001-2013 in comparison to cold winters (November-March), mild late winter (March-May) and warm and dry summer during 1988-2000. Further, the decrease in mean maximum as well mean minimum temperature during 2004-2013 is associated with change with inter-decadently of Pacific Oscillation and with increase in El Nino/southern Oscillation events that resulted in lower ablation season temperature particularly during summers of 2004-2014 (Yasunari, 1987) [16] (Figure 3 and Figure 4). This is further substantiated by decreasing trend in diurnal temperature during 2004-2013. These trends in weather conditions have undoubtedly 
leaded a favourable environment for decelerated retreat to the extent of no change in glacier area (120 glaciers) during last thirteen years (2001-2013) (Hewit, 2005) [17]. Further remaining 30 glaciers including Machoi glacier where detail field study (2011-2014) conducted, reveal slow retreat of glacier snout and marginal loss in glacier area (Kuhn, 1984) [18], hence substantiating that Drass sub basin glaciers are passing through stabilizing stage. Prior to the period 2001, the maximum and minimum temperature was low during winter as well summer dry leading to dry condition and as such, the glaciers of Drass valley were under climatic stress (Figure 2 and Figure 6) (Bahuguna et al., 2014; Ganjoo et al., 2014; Bolch et al., 2008) [19]-[21].

Table 5. Summary of net mass balance estimates of Machoi glacier (2011-2014).

\begin{tabular}{|c|c|c|c|c|c|c|c|}
\hline $\mathbf{Y}$ & Abl. area & Accu. Area & Net Abl. & Net Accu. & Net Bal. & AAR & Sp. ELA Bal. \\
\hline Teai & $\left(\mathrm{Km}^{2}\right)$ & $\left(\mathrm{Km}^{2}\right)$ & $\left(\mathrm{Km}^{3}\right)$ & $\left(\mathrm{Km}^{3}\right)$ & $\left(\mathrm{Km}^{3}\right)$ & & $\mathbf{m} / \mathbf{k m}^{2} / \mathrm{yr}(\mathrm{m})$ \\
\hline 2011-2012 & 2.219 & 3.54 & -2.748 & 3.709 & +0.960 & 0.615 & 0.174540 \\
\hline 2012-2013 & 2.100 & 3.62 & -2.585 & 3.261 & +0.675 & 0.636 & 0.124520 \\
\hline 2013-2014 & 1.933 & 3.83 & -2.263 & 3. 265 & +1.002 & 0.65 & 0.184509 \\
\hline
\end{tabular}

\section{Snout Position of Machoi Glacier (2012-2014)}
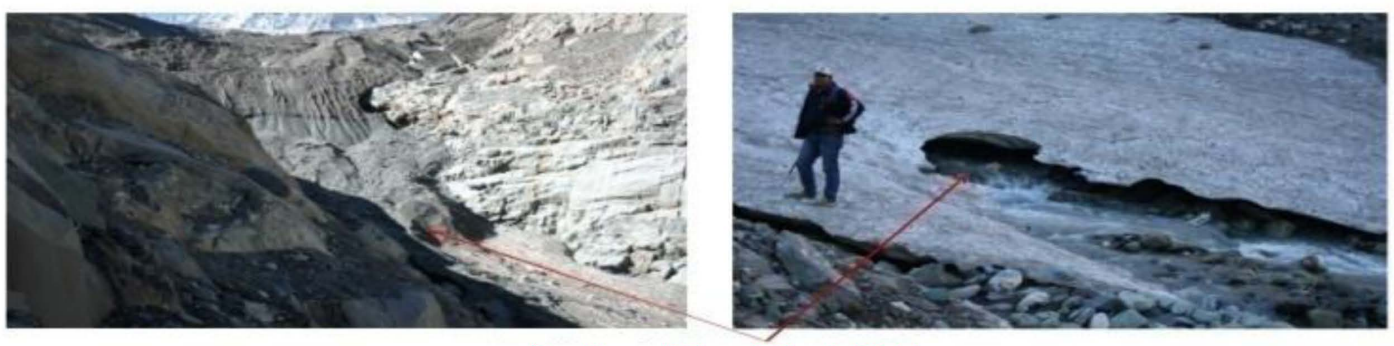

Position of Snout Sept. 2014

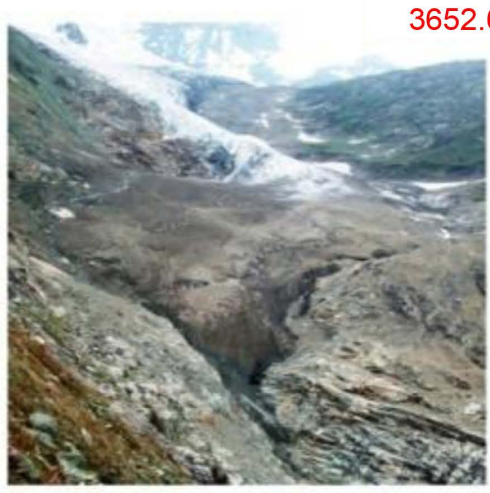

Position of Snout Sept. 2012 $3660.35 \mathrm{~m}$

$34^{\circ} 17^{\prime} 47.94 " \mathrm{~N} \& 75^{\circ} 3^{\prime} 42^{\prime \prime} \mathrm{E}$
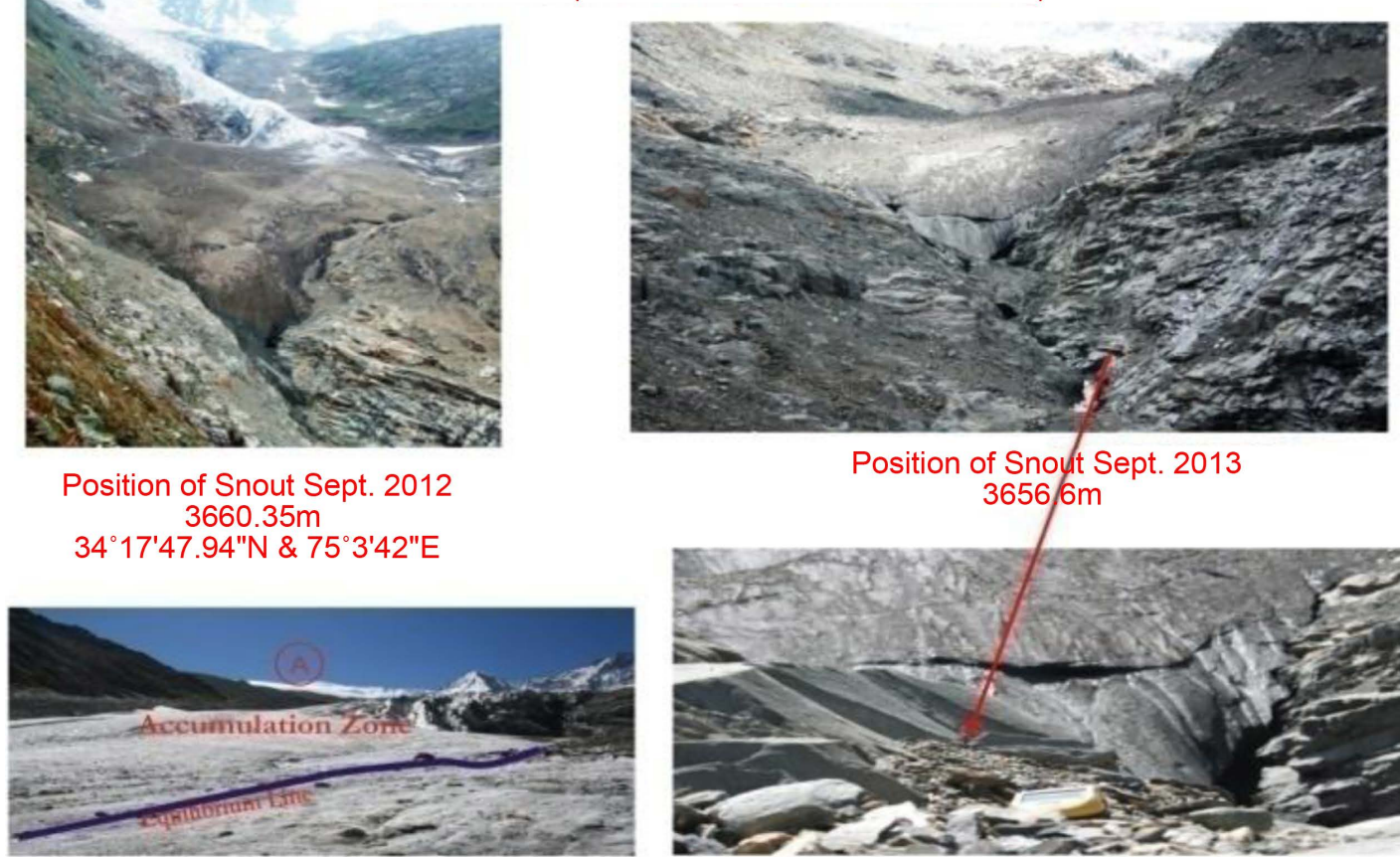

Position of Snoyt Sept. 2013 $3656 / 6 \mathrm{~m}$

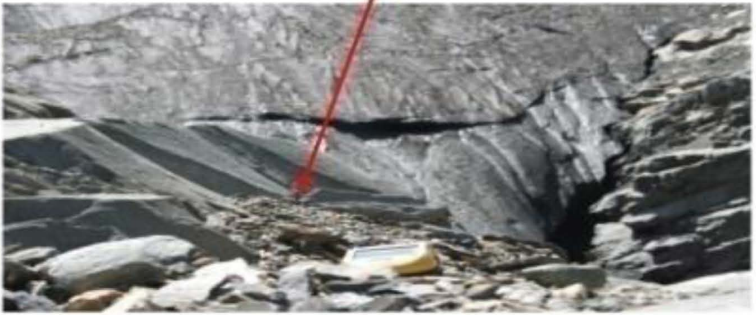

$34^{\circ} 17^{\prime} 41.85^{\prime \prime} \mathrm{N} \& 75^{\circ} 31^{\prime} 41.27^{\prime \prime} \mathrm{E}$

Figure 9. Machoi glacier: fluctuation records of snout position from 2012-2014. 
Machoi glacier selected as benchmark glacier in Drass basin, has been monitored and studied by many geologists/glaciologists in the past 130 years. A photograph of glacier published in book, "Valley of Kashmir" by Lawrence 1895 [22] shows the extension of Machhoi glacier up to rock cliff (Photograph, 1875) closely in contact with base of lateral moraine ridge. The glacier was relatively much thicker than at present and narrow in lateral valley. In 1895 RD Oldham [23] of the geological survey of India visited the glacier. According to him the glacier is about half mile from the road head, has evidently extended almost down to where road now runs and is shown by heaps of moraines material. His observation was also confirmed by La Touche (1910) [24] and Raina (1971) [25]. The geomorphologic evidences (high lateral moraines, terminal moraine and recession moraine) document that Machoi glacier in the ancient times extended up to the altitude of $3410 \mathrm{~m}$ and joined main Gumri valley glacier. The scars of Machoi glacier deposits observed on the side of Gumri River in the form of remnant moraines breached at several places. The research team of university of Jammu extensively monitored the glacier from the snout to the altitude of $4800 \mathrm{~m}$ (accumulation zone) by GPS survey and carried continuous field mass balance measurements during 2011 to 2014. The glacier has a positive net balance with cumulative specific balance of $0.16 \mathrm{~m}$ w.e. $/ \mathrm{km} / \mathrm{yr}$. This has resulted in shifting ELA from $4540 \mathrm{~m}$ asl in the year 2011-2012 to $4509 \mathrm{~m}$ asl 2013-2014 (Table 5) and the glacier snout to advance 4 meters in central part (3656 m to $3652 \mathrm{~m}$ ), but along the sides there has been deformation squeezing and retreat $(0.56 \mathrm{~m})$ (Figure 9$)$.

\section{Acknowledgements}

The authors express thanks to the Ministry of Environment and Forests, Government of India and Space Application Centre, Ahmedabad (ISRO) for the financial and collaborative support.

\section{References}

[1] Bahadur, J. (2001) Glaciations over Himalaya-The Tallest Water Tower. Proceedings of the National Academy of Sciences, India, Allahabad, 25-26 August 2000, 38-49.

[2] Koji, F. (20008) Effect of Precipitation Seasonality on Climate Sensitivity of Glacier Mass Balance. Earth and Planetary Science Letters, 276, 1-2, 14-19.

[3] Bitz, C.M. and Battissi, D.S. (1999) Interannual to Decadal Variability of Climate and Glacier Mass Balance in Washington, Western Canada and Alaska. Journal of Climate, 12, 3181-3196. http://dx.doi.org/10.1175/1520-0442(1999)012<3181:ITDVIC>2.0.CO;2

[4] Bowling, S.A. (1977) Relation between Temperature and Snowfall in Interior Alaska. Arctic, 30, 62-64.

[5] Yadev, R.R., Park, W.K., Singh, J. and Dubey, B. (2004) Do the Western Himalaya Defy Global Warming? Geophysical Research Letters, 31, L17201. http://dx.doi.org/10.1029/2004gl020201

[6] Fowler, H.J. and Archer, D.R. (2006) Conflicting Signals of Climatic Change in Upper Indus Basin. Journal of Climate, 19, 4276-4293. http://dx.doi.org/10.1175/JCLI3860.1

[7] Bhutiyani, M.R., Kale, V.S. and Pawar, N.J. (2007) Long-Term Trends in Maximum, Minimum and Mean Annual Temperatures across the Northwestern Himalaya during Twentieth Century. Climate Change, 89, 159-177. http://dx.doi.org/10.1007/s10584-006-9196-1

[8] Koul, M.N. and Ganjoo, R.K. (2010) Impact of Inter- and Intra-Annual Variation in Weather Parameters on Mass Balance and Equilibrium Line of Naradu Glacier ( Himachal Pradesh) NW Himalaya, India. Climate Change, 99, 119-139. http://dx.doi.org/10.1007/s10584-009-9660-9

[9] Kaul, M.N. (1986) Mass Balance of Liddar Glaciers. Transactions of the Institute of Indian Geographers, 8, 95-111.

[10] Haeberli, W. and Beniston, M. (1998) Climate Change and Its Impact on Glaciers and Permafrost in Alps. Ambio, 27, 258-265.

[11] Kulkarni, A.K., Mathur, P., Rathore, B.P., Alex, S., Thakur, N. and Kumar, M. (2002) Effect of Global Warming on Snow Ablation Pattern in Himalaya. Current Science, 88, 1844-1850.

[12] Singh, P., Haritashya, U.K., Ramasastri, K.S. and Kumar, N. (2005) Prevailing Weather Condition during Summer Season around Gangotri Glacier. Current Science, 88, 753-760.

[13] Karl ,T.R., Groisman, P.Y., Knight, R.W. and Heimjr, R.H. (1993) Recent Variations of Snow Cover and Snowfall in North America and Their Relation to Precipitation and Temperature Variations. Journal of Climate, 6, 1327-1344. http://dx.doi.org/10.1175/1520-0442(1993)006<1327:RVOSCA>2.0.CO;2

[14] Mayer, C., Lambrecht, A., Belo, M., Smiraglia, C. and Diolaaiuti, G. (2006) Glaciological Characteristics of the Ablation Zone of Baltoro Glacier, Karakorum, Pakistan. Annals of Glaciology, 43, 123-131. 
http://dx.doi.org/10.3189/172756406781812087

[15] Ohmura, A., Kasser, P. and Funk, M. (1992) Climate at Equilibrium Line of Glacier. Journal of Glaciology, 38, 397411.

[16] Yasunari, T. (1987) A Global Structure of EL-Nino Southern Oscillation Part 1: EL-Nino Composites. Journal of the Meteorological Society of Japan, 65, 67-80.

[17] Hewit, K. (2005) The Karakorum Anomaly? Glacier Expansion and the "Elevation Effect”, Karakorum Himalaya. Mountain Research and Development, 25, 332-340. http://dx.doi.org/10.1659/0276-4741(2005)025[0332:TKAGEA]2.0.CO;2

[18] Kuhn, M. (1984) Mass Budget Imbalances as a Criterion for Climatic Classification of Glaciers. Geografiska Annaler, 66, 229-238. http://dx.doi.org/10.2307/520696

[19] Bahuguna, I.M., Rathore, B.P., Brahmbhatt, R., Sharma, M., Dhar, S., Randhawa, S.S., Kumar, K., Romshoo, S., Shah, R.D., Ganjoo, R.K. and Ajai (2014) Are the Himalayan Glaciers Retreating? Current Science, 106, 1008-1015.

[20] Ganjoo, R.K., Koul, M.N., Bahuguna, I.M. and Ajai (2014) The Complex Phenomenon of Glaciers of Nubra Valley, Karakorum (Ladakh), India. Natural Science, 6, 733-740. http://dx.doi.org/10.4236/ns.2014.610073

[21] Bloch, T., Buchroithener, M.T. and Kunert, A. (2008) Plan Metric and Volumetric Glacier Changes in the KhumbuHimal, Nepal Since 1962 Using Corona, LANDSAT TM and ASTER Data. Journal of Glaciology, 54, 592-600. http://dx.doi.org/10.3189/002214308786570782

[22] Lawrence, W.R. (1895) The Valley of Kashmir. Henry Froude Oxford University Press, London.

[23] Oldham, R.D. (1904) Notes on the Glaciations and History of the Sind Valley, Kashmir. Records of the Geological Survey of India, 31, 142-161.

[24] Latouchi, T.H.D. (1910) Notes on Certain Kashmiri Glaciers. Records of the Geological Survey of India, 4, 4.

[25] Raina, V.K. (1971) The Snout of the Machoi Glacier, Kashmir. Records of the Geological Survey of India, 96, 51-54. 